\title{
The pandemic's wake-up call for humanity-centered public diplomacy
}

\author{
R. S. Zaharna ${ }^{1}$ \\ Revised: 20 September 2021 / Accepted: 26 September 2021 / Published online: 27 October 2021 \\ (c) The Author(s), under exclusive licence to Springer Nature Limited 2021
}

\begin{abstract}
The pandemic is re-shaping the global public's perspective of state-centric public diplomacy in a way that prioritizes the shared connection of humanity and a humanity-centered public diplomacy. This piece explores the gaps of where public diplomacy is and public diplomacy's new global mandate for collaborative problem solving for the global good.
\end{abstract}

Keywords Global mandate $\cdot$ Soft power $\cdot$ Humanity-centered public diplomacy $\cdot$ Empathy

Iver Neumann observed that "humanity shapes diplomacy, and diplomacy shapes humanity" (2018, p. 4). The surge of interest in public diplomacy following the 9/11 terrorist attacks underscores Neumann's observation. The attacks were a wake-up call that the perception of foreign publics mattered. Diplomacy responded to the oversight with a shift from traditional diplomacy as statecraft, to a renewed focus on public diplomacy. The pandemic appears to be another wake-up call. This brief essay explores how the pandemic has exposed a growing gap between state-centric and humanity-centered public diplomacy, perceptions of soft power as well as needed additions to public diplomacy practices.

\section{State perspectives of Covid-19, public diplomacy and soft power}

In looking at the pandemic, the state perspective appears focused on public diplomacy and soft power repercussions of how effectively they managed the virus compared to other states (Leng and Lemahieu 2021). Socially Distanced Soft Power, for example, focused on "the pandemic's impact on the reputation of given countries and regions" and "the global balance of soft power" (McClory 2021). Efforts to

For special issue-Ilan Manor and James Pamment.

R. S. Zaharna

zaharna@american.edu

1 School of Communication, American University, 4400

Massachusetts Ave, NW, Washington, DC 20016-8017, USA help others were framed in terms of how they enhanced a state's image. "Vaccine diplomacy" was added to wikipedia.

This focus on state interests and power has long been part of the DNA of public diplomacy, from the early works of Joseph Nye (2004) and Jan Melissen (2005) to more recent scholarship (Chitty 2020; Hayden 2012; Pamment 2016). As Nancy Snow observed, public diplomacy is "inevitably linked to power" (2020, p. 4). Yet even more basic than the assumption of power is the presumed focus on the individual actors and their relations to other actors. Soft power exemplifies the individual-level perspective of public diplomacy and its inherent competitive nature.

The pandemic offers an opportunity to question this individual-level, power-focused, and competitive perspective of public diplomacy. How are publics viewing states, public diplomacy and soft power during the pandemic?

\section{Public perspectives of the pandemics and state soft power}

Perhaps the most striking difference between state and public perspectives is that for publics there is not one "pandemic" but multiple, compounding crises.

First came the Covid-19 virus. For global publics, Covid19 was a "mortality shock" (Verdery et al. 2020). What were statistic and logistics for states, were loved ones for families. The emotional toll multiplied when pandemic precautions separated family members and arrested the grieving process. As governments focused in public health measures to contain the virus-lockdowns, quarantines, social 
distancing-researchers warned of a second, impending "psychiatric pandemic" (Abbott 2021; Mortazavi et al. 2020).

A third, related crisis of Covid-19 was the financial toll not only on states' tourism and economies, but people's livelihoods worldwide (OECD 2021). The loss of jobs, income, and sense of worth compounded the emotional strain on families. Domestic violence increased globally, creating a "shadow pandemic" (Vaeza 2020).

Then, in May 2020, the video of a police officer kneeling on the neck of a Black man, George Floyd, lit an emotional fire that spread worldwide. The pandemic exposed health and economic disparities targeting people of color (Laurencin and Walker 2020). As many protest signs read: "Racism is a pandemic."

These multiple pandemics affecting global publics sparked not only an awareness of shared global problems but also a shared feeling of connection with others around the world. Emotional connection or global fellowship is at the heart of a humanity-centered perspective of public diplomacy.

This emotional connection surfaced as the prism for viewing the actions of nations and soft power. As writer Sundeep Khanna (2020) voiced in a biting analysis of how traditional soft powers had failed: "It wasn't just how they dealt with the virus at home but how in this moment of civilisational crisis countries dealt with the rest of the world that will have a long-term impact on how we see them." Similarly, an editorial from City/Nation/Place.com (2020) argued: "The ideals of global citizenship and camaraderie were put to the test, and the world's purportedly most open and democratic states responded by closing up shop."

States did more than just fail the Covid-19 test; they failed the humanity test. Increasingly, publics expect governments to act in the global interest. The 2018 Soft Power 30 Report noted this trend before the pandemic: "the area that has the largest impact on international perceptions of a country-is whether people believe that a given country will "do the right thing in global affairs"(McClory 2018, p. 165). Simon Anholt made a similar observation about the effect of moral behavior on the perception of countries: people admire countries who do good (2020, pp. 117-118). In 2014, he founded the Good Country Index.

Public diplomacy must address this gap between global publics' concern for pressings issues that affect humanitymany of which the Covid-19 pandemic exposed or exacerbated-and states' concern with individual power.

A growing chorus of scholars have highlighted this imperative. Castells spoke of "the diplomacy of the public" that promoted the value of public interests over private ones. Zhang and Swartz (2009) suggested "public diplomacy for Global Public Goods." Fitzpatrick (2017) proposed "public diplomacy in the public interest." As Villaneuva noted, "attending to the international common good makes for sound diplomacy" (2010, p. 46). I have written on humanitycentered public diplomacy elsewhere and it is the subject of a forthcoming book, Boundary Spanners of Humanity (Zaharna 2019, 2021). All of these writings call for expanding public diplomacy from its narrow focus on the needs, interests, and goals of individual actors to include the broader needs, interests, and goals of humanity.

\section{Expanding the public diplomacy's functions}

As we expand public diplomacy's vision to a humanity-centered perspective, we must also reassess or add new functions to public diplomacy's toolbox. Several areas stand out.

\section{Develop response strategies}

Public diplomacy is somewhat peculiar in assuming that states have agency and can even target publics. What happens when states lack agency, such as with the pandemic? What happens when instead of states targeting publics, publics target states? Social media amplifies this possibility, "forc[ing] soft power strategies to become more reactive than in decades prior" (Snyder and Sindyukov 2020). The pandemic's compounded crises were flash points for states. "Rage is a powerful sentiment, and the pandemic set it off up and down the country," observed one commentator in Peru (Lane 2021). Castells (2012) warned earlier about "networks of rage." The urgency of developing crisis response strategies is superseding the luxury of designing strategic initiatives. As the pandemic demonstrated, how a state responds communicates volumes to observing publics.

\section{Move from listening to perspective-taking}

In developing effective response strategies with a humanity-level perspective, public diplomacy actors need to move beyond listening to perspective-taking. Cull $(2008,2019)$ and Di Martino (2020) have greatly sharpened public diplomacy's focus by prioritizing the importance of listening. My fear now is that the pandemic has shaken communication dynamics so profoundly that listening, or taking in information, is no longer enough. Perspective-taking goes to the next step of processing that information from the other's perspective, including a humanity-level perspective. 


\section{Empathetic public diplomacy}

Whereas empathy may be a fuzzy concept for rational state actors, for publics it is a critical release valve in crisis situations when fear and uncertainty become overwhelming or even explosive. The pandemic offers a brilliant demonstration of empathetic diplomacy. In April 2020, Queen Elizabeth made a rare, televised speech. Rather than focusing on the virus as an enemy to fight, as other leaders did, she spoke to the feelings of the people. She opened with empathy, legitimizing public fears and the pain of separation. She gave solace to grief and a promise of hope: "We will be with our friends again; we will be with our families again; we will meet again." The Queen's speech, intended for the Commonwealth, resonated around the globe. Empathy is a vital function in a humanity-level response to global publics.

\section{Public diplomacy's global mandate for collaborative problem solving}

The most critical public diplomacy function, and the one at which states failed most miserably at during the pandemic, is collaborative problem-solving. The $2021 \mathrm{soft}$ power report noted the difference between scientific research teams as "exemplars of international cooperation" and the collective failures of the world's political leaders (McClory 2021, p. 16). This difference reveals the limitations of the inherently competitive individual-level perspective set against an expansive humanity-level perspective that assumes connectivity and by extension, collaboration. Awareness of a shared fate may have also spurred scientists to focus on problemsolving rather than their team's own prestige (soft power). Going forward, publics—like the scientists-may also sense their shared fate in global problems. Public diplomacy may be "inevitably linked to power," as Snow suggested. However, public diplomacy is fundamentally about publicshumanity. The global public's concern about the growing frequency and severity of crises affecting humanity and the planet may be shaping public diplomacy's new global mandate for collaborative problem-solving for the global good. Humanity, may once again, shape diplomacy.

\section{References}

Abbott, A. 2021. COVID's mental-health toll: How scientists are tracking a surge in depression. Nature 590 (7845): 194-195. https:// doi.org/10.1038/d41586-021-00175-z.

Anholt, S. 2020. The good country equation: How we can repair the world in one generation. Oakland: Berrett-Koehler.

Castells, M. 2012. Networks of outrage and hope: Social movements in the internet age. Cambridge: Polity.
Chitty, N., ed. 2020. The Routledge handbook of soft power, 1st ed. London: Routledge.

CityNationPlace.com. 2020. Has the pandemic killed soft power? City Nation Place. https://www.citynationplace.com/has-the-pande mic-killed-soft-power.

Cull, N.J. 2008. Public diplomacy: Taxonomies and histories. The Annals of the American Academy of Political and Social Science 616: 31-54.

Cull, N.J. 2019. Public diplomacy: Foundations for global engagement in the digital age, 1 st ed. Cambridge: Polity.

Di Martino, L. 2020. Conceptualising public diplomacy listening on social media. Place Branding and Public Diplomacy 16 (2): 131 142. https://doi.org/10.1057/s41254-019-00135-5.

Fitzpatrick, K.R. 2017. Public diplomacy in the public interest. Journal of Public Interest Communication 1 (1): 78-93.

Hayden, C. 2012. The rhetoric of soft power: Public diplomacy in global contexts. Lanham: Lexington Books.

Khanna, S. 2020. Will COVID-19 upend our notions of soft power? [Opinion]. Moneycontrol. https://www.moneycontrol.com/news/ opinion/will-covid-19-upend-our-notions-of-soft-power-61207 51.html.

Lane, C. 2021. The tragic decay of a Latin American success story. Washington Post, A25.

Laurencin, C.T., and J.M. Walker. 2020. A pandemic on a pandemic: Racism and COVID-19 in blacks. Cell Systems 11: 9-10.

Leng, A., and H. Lemahieu. 2021. Covid performance index: Deconstructing pandemic responses [interactives]. Lowy Institute. https://interactives.lowyinstitute.org/features/covid-perfo rmance/.

McClory, J. 2018. Soft Power 30-2018. Portland Group and USC Center on Public Diplomacy. https://softpower30.com/wp-conte nt/uploads/2019/10/The-Soft-Power-30-Report-2019-1.pdf.

McClory, J. 2021. Socially distanced diplomacy: The future of soft power and public diplomacy in a fragile world. Sanctuary Counsel and USC Center on Public Diplomacy. https://uscpu blicdiplomacy.org/sites/default/files/Sanctuary\%2BCounsel\% 2Bx\%2BCPD_Socially\%2BDistanced\%2BDiplomacy\%2BRep ort_May\%2B2021.pdf.

Melissen, J. 2005. The new public diplomacy: Between theory and practice. In The new public diplomacy: Soft power in international relations, 3-27. Palgrave Macmillan.

Mortazavi, S.S., S. Assari, A. Alimohamadi, M. Rafiee, and M. Shati. 2020. Fear, loss, social isolation, and incomplete grief due to COVID-19: A recipe for a psychiatric pandemic. Basic and Clinical Neuroscience 11 (2): 225-232. https://doi.org/10. 32598/bcn.11.covid19.2549.1.

Neumann, I.B. 2018. A prehistorical evolutionary view of diplomacy. Place Branding and Public Diplomacy 14: 4-10.

Nye, J.S. 2004. Soft power: The means to success in world politics. PublicAffairs.

OECD. 2021. Tackling the mental health impact of the COVID-19 crisis: An integrated, whole-of-society response. OECD. https:// www.oecd.org/coronavirus/policy-responses/tackling-the-mental-health-impact-of-the-covid-19-crisis-an-integrated-wholeof-society-response-0ccafa0b/.

Pamment, J. 2016. British public diplomacy and soft power: Diplomatic influence and the digital revolution, 1st ed. 2016 edition. Basingstoke: Palgrave Macmillan.

Snow, N. 2020. Rethinking public diplomacy. In Routledge handbook of public diplomacy, 2nd ed., ed. N. Snow and N.J. Cull, 3-12. London: Routledge.

Snyder, A., and M. Sindyukov. 2020. How Covid-19 is changing the soft power game. Diplomatic Courier.

Vaeza, N.-N. 2020. Addressing the impact of the COVID19 pandemic on violence against women and girls. United Nations; United Nations. https://www.un.org/en/ 
addressing-impact-covid-19-pande mic-violence-again st-women-and-girls.

Verdery, A.M., E. Smith-Greenaway, R. Margolis, and J. Daw. 2020. Tracking the reach of COVID-19 kin loss with a bereavement multiplier applied to the United States. Proceedings of the National Academy of Sciences 117 (30): 17695-17701. https:// doi.org/10.1073/pnas.2007476117.

Villaneuva Rivas, C. 2010. Cosmopolitan constructivism: Mapping a road to the future of cultural and public diplomacy. Public Diplomacy Magazine Winter (3): 45-56.

Zaharna, R.S. 2019. Culture, cultural diversity and humanity-centred diplomacies. The Hague Journal of Diplomacy 14 (1-2): 117133. https://doi.org/10.1163/1871191X-14101018.

Zaharna, R.S. 2021. Boundary spanners of humanity: Three logics of human communication and public diplomacy. Oxford: Oxford University Press.

Zhang, J., and B.C. Swartz. 2009. Public diplomacy to promote Global Public Goods (GPG): Conceptual expansion, ethical grounds, and rhetoric. Public Relations Review 35 (4): 382-387.
Publisher's Note Springer Nature remains neutral with regard to jurisdictional claims in published maps and institutional affiliations.

R. S. Zaharna is a professor in the School of Communication, American University, Washington, D.C. and Faculty Fellow, with Center on Public Diplomacy, University of Southern California. She received the 2018 Distinguished Scholar Award in International Communication by the International Studies Association. Her books include Battles to Bridges: U.S. Strategic Communication and Public Diplomacy after 9/11 (Palgrave, 2010) and Boundary Spanners of Humanity: Three Logics of Communication and Public Diplomacy for Global Collaboration (Oxford University Press, 2021). 